\title{
Economic Contribution of Women in Watershed Development
}

\author{
Jacqueline V. Iglesias ${ }^{1}$, Mild R. Hombrebueno ${ }^{2}$
}

\begin{abstract}
Nueva Vizcaya, State University Bayombong, Nueva Vizcaya Philippines
Abstract: This study zooms into the economic contribution of women engaged in watershed development vis a vis climate change adaptation, mitigation and sustainability practices in Nueva Vizcaya, Philippines. Women farmers usually own less than a hectare of land and plant palay, corn, vegetables as their common crops.They play vital economic contribution in crop/vegetable production like planting, fertilizing and harvesting as well as feeding, herding and marketing in livestock/animal production. They perform productive, managing and reproductive work, which are not compensatory with money- these activities do not have salary. Off-farm activities like food processing their own products (ginger-making, tomato sauce making), making walis-tambo, environmental-friendly business like recycling-bakalbote), women farmers can increase their economic contribution. By these technologies, they come to truly realize their potentials as economic contributors and thereby realized also that by doing so, they have empowered themselves.This research recommends that policies about women should be strengthened even at the grassroots level. Their role and part in the family, community and society are deemed necessary that could not be neglected as this study shown. As the future trajectory of the research government should be on MATERNAL HEALTH.
\end{abstract}

Keywords: climate changes, economic contribution, women, adaptation, mitigation

\section{Introduction}

Women play a vital role in our society. The journey of women in the road of gender equality cannot be underestimated. In a patriarchal society like the Philippines, where men are considered to dominate most or if not all aspects of life, women are regarded as subordinates especially when it comes to decision-making, representation in political affairs, economic activities, production and labor force. Women have been silenced for long years, however the realizations of women's contribution to nation-building and integration as equal partners of men in development paved the way as reflected in Republic Act 7192 of 1991 (Women in Development and Nation Building Act).

Thus, seminar-trainings, workshops and researches have focused on the gender sensitivity and women empowerment; which highlight and recognize the contribution of women in all aspects of life. One of these important roles of women is the role on watershed development given the context of modernization and globalization accompanied with the pressing issue of climate change in the $21^{\text {st }}$ century.

Nueva Vizcaya is known to be the watershed haven of the Valley in Region II. Given this context, this study zooms into the economic contribution of women engaged in watershed development vis a vis climate change adaptation, mitigation and sustainability practices in Nueva Vizcaya.The study shall serve as a benchmark data for planners on the economic contribution to watershed development particularly in the exercises of women's different functions as productive, reproductive and managing activities that are inherent to women.

In like manner, the study is significant to the value of women as they play the role in watershed development for sustainable development. The findings will benefit the following:

1) Planners - Watershed planners using the agricultural profile

2) Watershed developers in the different watershed areas. Result can be piloted in other areas of the country.

3) Economic - planners to provide validation on contribution of women in sustainable development

4) LGUnits in all the different watershed areas

5) Researchers to develop new study as a result of this program

6) Extensionists to extend generated technologies

\section{Review of Literature}

The changing role of women and growing awareness of their economic inequality with respect to men have brought international attention to women's issues in the West in recent decades. The feminist movement, however, seems less effective in Asian countries, be they developed like Japan, newly developed like Taiwan, Korea, Singapore and Hong Kong or less-developed like ASEAN countries, China and India.

Although most Asian countries have developed less than their western industrialized counterparts, Asia's rate of recent economic growth has greatly exceeded all other regions. Nevertheless countries in Asia do not share the same level of economic development. It is, therefore, of great interest to know what women's economic positions are in Asian countries and particularly in the Philippines with different economic development levels and how much their positions have improved with economic status of women in Northeast and Southeast Asia.

A seemingly common belief is that the economic condition of women improves with economic development. This is because economic development improves the population's economy, thereby prompting remedial action.

As much as this is a logical belief, the terribly disadvantaged economic position of women in the highly developed Japanese economy seems to suggest that economic development is not the only factor which affects women's economic status. Note that when talking about women's economic development certainly can improve everybody's economic status, but it does not necessarily improve the position of women relative to men. Furthermore, if traditional attitudes are deeply rooted in the society, it may take a long time for them to be an acknowledgement of women's subordinate position and attempts to improve it. Asian countries, generally, have long histories. Their male- dominated cultures have had a long, ingrained influence on all aspects of Asian life. As corrected pointed out by Gunderson (1994):

Discrimination in the developing countries tends to be more overt, with all parties (employers, males and even females)often adhering to traditional attitudes about what jobs are suitable and proper for women, and what pay is appropriate' given perceptions about who is the breadwinner'.

This comment seems relevant to most, if not all, Asian countries regardless of development. Women's economic 


\section{International Journal of Science and Research (IJSR)}

ISSN (Online): 2319-7064

Index Copernicus Value (2013): 6.14 | Impact Factor (2015): 6.391

position compared to men's depends on (1) their labor force participation in the wage -earning sector, (2) their occupational attainment, (3) their relative wage level and (4) the time they spend working at home which, as economic theory suggest, reduces the time they can spend in paid employment (Becker, 1965; Mincer, 1962; Gronau,1980). Home production is a very important element of women's economic activity and an important aspect of women's important element of women's relative economic position. www.iisg.nl/clara/publicat/clara4.pdf, December 13,2011 @ 4:.00 p.m.)

\section{Procedure/Methodology}

The study is a primarily descriptive research. It focused on women who engage in watershed development and climate change adaptation and mitigation in Nueva Vizcaya. It also used focus-group discussion to substantiate data collected from the questionnaire. The data on the economic contribution of women were also analyzed using the following:

1. Time allocation for productive, managing and reproductive work; and

2. Wage equivalent per day for performing productive, managing \& reproductive work.

\section{A. Research design}

The study used a descriptive research design utilizing a survey questionnaire and focus group discussion in order to substantiate and complement the numeric data from the survey.

Table 2: Demographic Profile of the Population and Sample

\begin{tabular}{|c|c|c|c|c|}
\hline Municipality & $\begin{array}{c}\text { Total Number of } \\
\text { RIC members }\end{array}$ & $\begin{array}{c}\text { Expected } \\
\text { Respondents }\end{array}$ & $\begin{array}{c}\text { Number of respondents } \\
\text { interviewed }\end{array}$ & Date the survey was conducted \\
\hline Ambaguio & 124 & 8 & 11 & October 31, 2013 \\
\hline Bagabag & 269 & 17 & 35 & August 30 - September 1, 2013 \\
\hline Bayombong & 1376 & 88 & 100 & July 4 \& September 4, 2013 \\
\hline Diadi & 255 & 16 & 16 & November 4, 2013 \\
\hline Dupax del Sur & 183 & 12 & 21 & November 5, 2013 \\
\hline Quezon & 319 & 20 & 23 & September 5, 2013 \\
\hline Kayapa & 594 & 38 & 35 & June 27 \& July 3, 2013 \\
\hline TOTAL & 3120 & 200 & 241 & \\
\hline
\end{tabular}

Table 2 shows the population and respondents for the study. The purposive sampling was used to determine the population of the study in Nueva Vizcaya. Out of 14 municipalities in Nueva Vizcaya, there were seven (7) municipalities or eight barangays where the surveys were conducted with a total number of 241 respondents. These were 1) Masoc, Bayombong with 38 respondents; Bansing, Bayombong with 62 respondents; 2) Alicia and San Fabian, Kayapa with 35 respondents; 3) Nangalisan, Bagabag with 35 respondents; 4) Poblacion, Ambaguio with 11 respondents; 5) Buliwao, Quezon with 23 respondents; 6) Parai, Dupax Del Norte with 21 respondents; and 7) Villa Aurora, Diadi with 16 respondents. The encoded data were given to Marla A. Hernandez, the Climate Change Program resident statistician for statistical analysis.

\section{B. Instrument of the Study}

The structured survey questionnaires were administered through the interview schedules. The questionnaire was divided into four (4) parts. Part 1 covers the agricultural profiles of women engaged in watershed development and climate change; Part II covers the participation of women in agricultural production technologies/practices on watershed areas and other complementary crops; Part III looks into the economic contribution of women in performing productive, managing and reproductive works; and Part IV determines the level of awareness adaptation \& mitigation \& sustainability practices on watershed development.

\section{Discussion of Results}

\section{A. Profile of Respondents}

The demographic profile of the respondents describes the characteristics of Rural Women in Nueva Vizcaya.

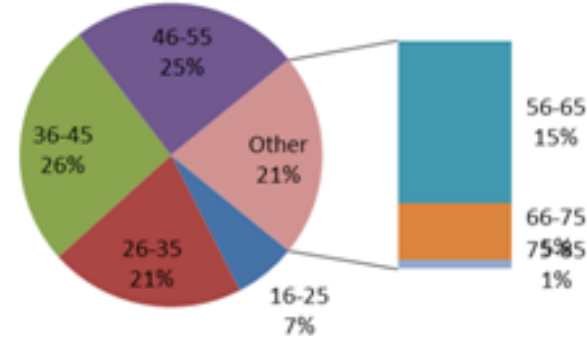

Figure 2: Frequency Distribution of Women when Grouped According Age

Figure 2.shows the demographic profile of women according to their age. Most of the respondents 63 (26\%) belong to the age group of $36-45$ years old, followed by the age groups 46 - 55 and 26 - 35 years old with 59 (25\%) and $51(21 \%)$ respectively. Least number of respondents $2(1 \%)$ belong to 76 - 85 years old. This suggests that the Rural women belong to the adulthood stage. This can be best explained that women are capable with the tedious task of agricultural activities.

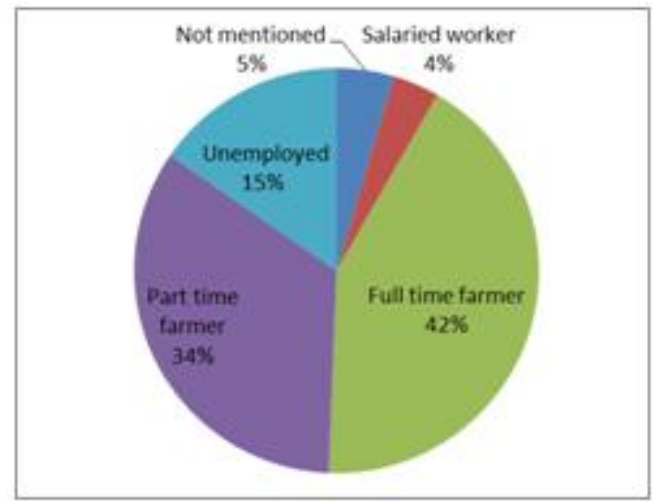

Figure 3: The Frequency Distribution of Women when grouped According to Occupation

Most Rural women in Nueva Vizcaya are full-time farmers Figure 3 indicates the Demographic Distribution of Women when grouped according to Occupation. Most of them 99 $(42 \%)$ are full-time farmers, $81(34 \%)$ are part-time farmers, $36(15 \%)$ are unemployed and $8(3 \%)$ are salaried workers. These full-time and part-time farmers plant and harvest 


\section{International Journal of Science and Research (IJSR)}

ISSN (Online): 2319-7064

Index Copernicus Value (2013): 6.14 | Impact Factor (2015): 6.391

Agricultural Crops and Vegetables. However, most of the parttime farmers are plain housewives who help their husband in their farm and vegetable production

Table 3: Frequency Distribution of the Respondents According to Highest Educational Attainment

\begin{tabular}{|c|c|c|}
\hline Highest Educational Attainment & Frequency & Percentage \\
\hline Pre-Primary/ Pre-School & 10 & $4.15 \%$ \\
\hline Primary/Elementary & 65 & $26.97 \%$ \\
\hline Secondary/ High School & 99 & $41.08 \%$ \\
\hline $\begin{array}{c}\text { Post Secondary Non-Tertiary/ } \\
\text { Technical Vocational }\end{array}$ & 6 & $2.49 \%$ \\
\hline Tertiary, First Stage/ Baccalaureate & 56 & $23.24 \%$ \\
\hline Tertiary, Second Stage/ Post-Graduate & 0 & $0.00 \%$ \\
\hline
\end{tabular}

Table 3 shows the demographic profile of women according to their Educational Attainment. There were $99(41.08 \%)$ women who graduated in High School, 65 (26.97\%) graduated in Elementary, 56 (23. 24\%) graduated in College, $10(4.15 \%)$ have no formal Schooling and $6(2.49 \%)$ took Vocational Courses. Most of the women are literate however their schooling was hindered because of poverty, early pregnancy and marriage. This lead to these women's notion of not finishing a degreesince they will soon be tied as full-time housewives.

Table 4: Frequency Distribution of Women According to Ethnic Group

\begin{tabular}{|c|c|c|}
\hline Ethnicity & Frequency & Percentage \\
\hline Ilocano & 129 & $53.53 \%$ \\
\hline Tagalog & 10 & $4.15 \%$ \\
\hline Pangasinan & 0 & $0.00 \%$ \\
\hline Kapampangan & 1 & $0.41 \%$ \\
\hline Cebuano & 18 & $7.47 \%$ \\
\hline Ifugao & 17 & $7.05 \%$ \\
\hline Ibaloi & 1 & $0.41 \%$ \\
\hline Isinay & 1 & $0.41 \%$ \\
\hline Gaddang & 0 & $0.00 \%$ \\
\hline Ikalahan & 11 & $4.56 \%$ \\
\hline Bugkalot & 14 & $5.81 \%$ \\
\hline Kankana - ey & 0 & $0.00 \%$ \\
\hline Ilongot & 1 & $0.41 \%$ \\
\hline Ibanag & 0 & $0.00 \%$ \\
\hline Iwak & 2 & $0.83 \%$ \\
\hline Ayangan & 0 & $0.00 \%$ \\
\hline Others & 2 & $0.83 \%$ \\
\hline
\end{tabular}

During the course of the interview, due to mix ethnic composition of some respondents, one could identify two or more ethnicity. But it is interesting to note that most of the respondents able to speak Ilocano dialect. Table 4 shows the Demographic Profile of Women when grouped according to ethnic group. Most of the interviewed women farmers 129 $(53.53 \%)$ are Ilocanos. Followed by Cebuano and Ifugao with $18(7.47 \%)$ and $17(7.05 \%)$ respectively. As shown, Cebuano and Ifugao come next as highest in percentages due to migration and inter-marriage from different islands of the Philippines.

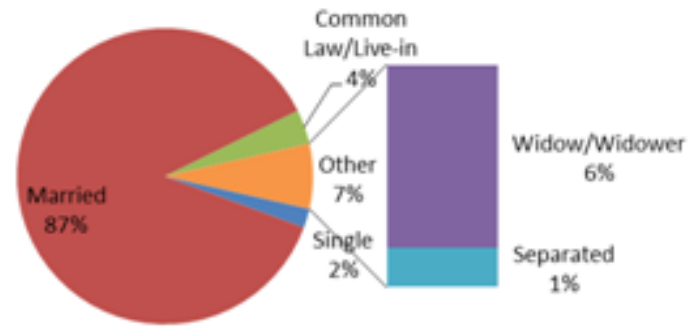

Figure 4: Frequency Distribution of Women According to Marital Status
Most of the respondents are married. Figure 4 shows thatNuevaVizcaya women are mostly married $179(87 \%)$. There were $36(15 \%)$ and $12(5 \%)$ who are single and widowed respectively. This shows that married women depend on agriculture as a viable source of income for the survival of one's family.

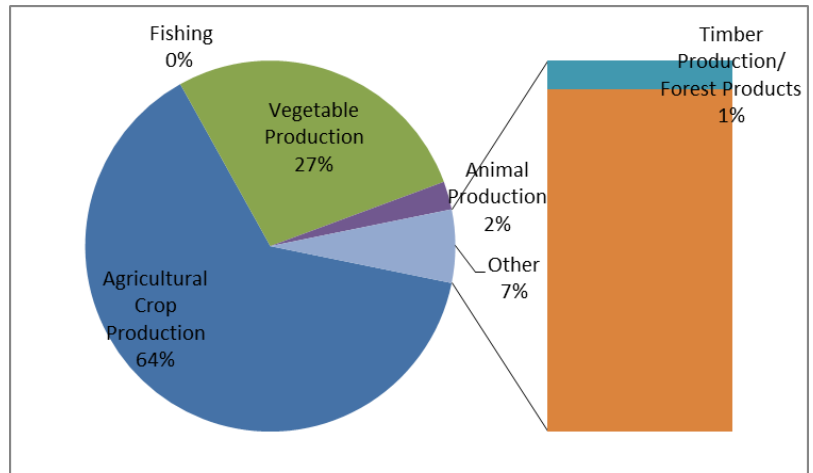

Figure 5: Percentage of Women According to source of Income

Figure 5 shows the Demographic Profile of women when grouped according to Source of income. Most of the respondents, $130(64 \%)$ of the respondents are engaged in agricultural crop production like palay, and corn. Followed by vegetable production (beans, cabbage, eggplant) and animal production (chicken, ducks, pig) with $56(27 \%)$ and $5(2 \%)$ women respectively.

\section{B. Agricultural Profile}

Most of the respondents have less than 1 hectare land area. Table 5 indicates the Agricultural Profile of Women when group according to Total Land Area. Most women farmers, $185(76.8 \%)$ own a total land area of $250-20,000$ hectares. These pieces of land include the land where their houses are built and their vegetable garden or backyard gardening are situated. The $29(12 \%)$ women farmers are tenants.

Table 5: Frequency Distribution of Women According to Total Land Area

\begin{tabular}{|c|c|c|}
\hline Total Land Area (ha) & Frequency & Percent \\
\hline 250 to 20,000 & 185 & 76.8 \\
\hline 20,001 to 40,000 & 14 & 5.8 \\
\hline 40,001 to 60,000 & 4 & 1.7 \\
\hline 60,001 to 80,000 & 6 & 2.5 \\
\hline 80,001 to 120,000 & 3 & 1.2 \\
\hline No response & 29 & 12.0 \\
\hline Total & 241 & 100.0 \\
\hline
\end{tabular}

Table 6 shows the Agricultural Profile of Women when grouped according to Land Tenure. Several women farmers are tenants, 94 (39\%). Most of them own the land, 87 (36\%). These women farmers use it for agricultural production as their main source of income. The Certified Land Managers of Department of Environmental and Natural Resources (DENR), comprised of $10(4.1 \%)$ women from Villa Aurora, Diadi and Parai, Dupax del Norte.

Table 6: Frequency Distribution of Women According to Land Tenure

\begin{tabular}{|l|c|c|}
\hline Land Tenure & Frequency & Percent \\
\hline Ancestral Owner & 10 & 4.1 \\
\hline Owner & 87 & 36.1 \\
\hline Tenant & 94 & 39.0 \\
\hline $\begin{array}{l}\text { Certified Land Managers by the } \\
\text { DENR }\end{array}$ & 10 & 4.1 \\
\hline Total & 241 & 100.0 \\
\hline
\end{tabular}

Figures 6 and 7 show the Agricultural Profile of Women when grouped according to Types of Crops Planted/Harvested and Livestock Raised respectively.Most women 135 (56\%), 84

Volume 5 Issue 6, June 2016 www.ijsr.net

Licensed Under Creative Commons Attribution CC BY 
(34.9\%), 72 (29.9\%), $54(22.4 \%) \& 52(21.6 \%)$ plan and harvest Rice, Corn, Banana, Tomato and String Beans respectively. These numbers indicate that women contribute to agricultural production of main crops in the province like palay and corn. Furthermore, the common livestock raised are Mallard Duck with 81 (33.6\%) of women, followed by women farmers raising cattle with 55 (22.8) and carabao with 34 $(14.1 \%)$ of the distribution. The increased number of women who raised cattle and carabao is due to the fact that farming is the main source of income and these animals are big help especially in these farming sites as mentioned in Table 2.

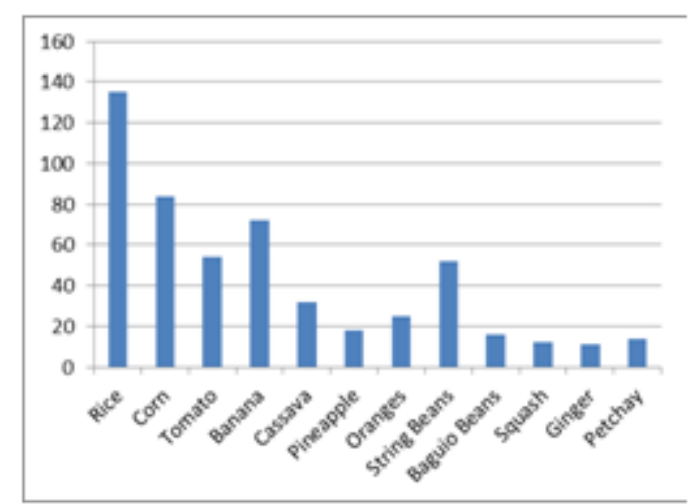

Figure 6: Frequency Distribution of Women According to Types of Crops Planted/Harvested

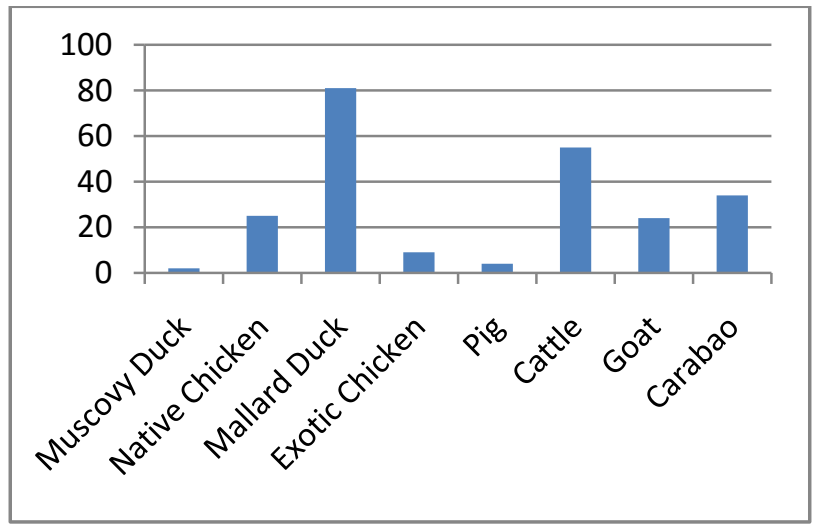

Figure 7: Frequency Distribution of Women According to Livestock Raised

\section{Participation of Women in Agricultural Production Technologies/Practices}

Rural Women of Nueva Vizcaya perform and assist their husbands in agricultural production technologies and practices. Figure 8 shows the Participation of Women in Crop/Vegetable Production Most women perform and aid their husbands in Planting, Fertilizationand Harvesting with 190 (79\%), $171(71 \%)$ and 177 (73\%). Women assist their husband in these agricultural activities since more hands are needed during the farming season. There are least number of women who perform sowing, processing and grain storage with 66 $(27 \%), 15(6.2 \%)$ and $22(9 \%)$ respectively. These agricultural activities are seldom performed by women because it takes physical strength and skill.

To further enhance the participation of women farmers in production technologies / practices, the researchers conducted training-seminar that capacitate and equip women farmers with skills in food processing as well as organic agriculture and fertilizer last March $13-14,2014$ at DFTC, Nueva Vizcaya State University.

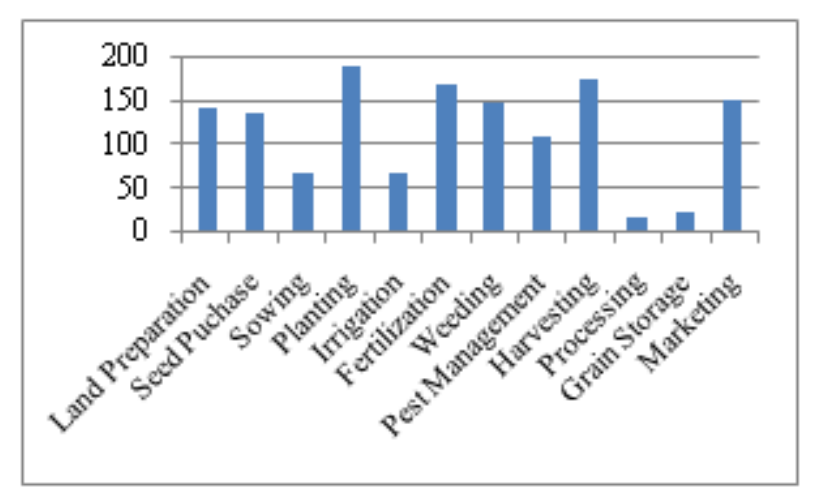

Figure 8: Frequency Distribution of the Participation of Women in Crop/Vegetable Production

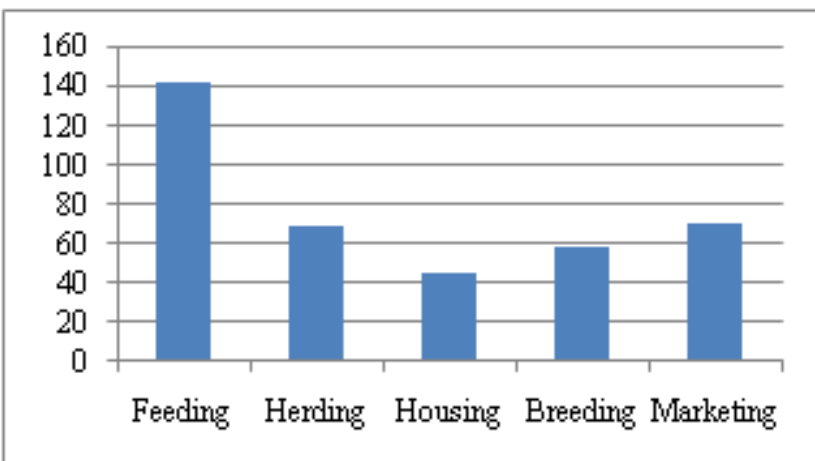

Figure 9: Frequency Distribution of the Participation of Women in Animal Production/Livestock Production

Aside from the Crop/Vegetable Production, women also perform and assist their families in Animal/Livestock Production. Figure 9 shows the Participation of Women in Animal/Livestock Production. They usually perform activities such as Feeding with 142 (59\%), Marketing with 70 (29\%), Herding with 69 (29\%), Breeding with 59 (25\%) and Housing with 69 (29\%)of women. The feeding activity is done early morning and late in the afternoon. The marketing strategy that they used is the Iloko term "sursur or they usually sell their products visiting houses within their barangay.

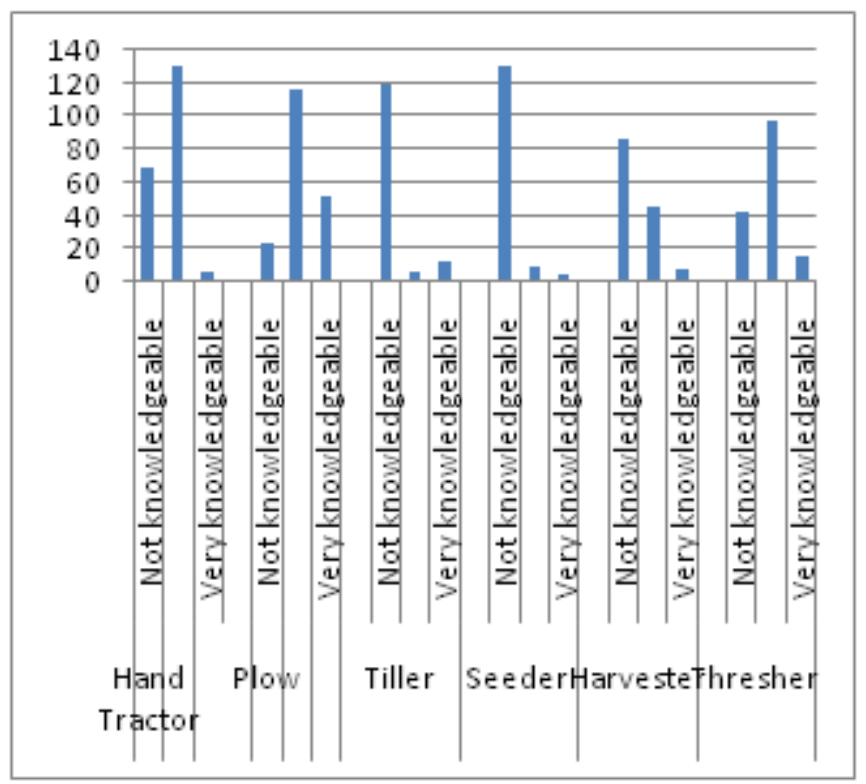

Figure 10: Frequency Distribution of the Participation of Women in terms of their Knowledge in Farm Machines

The women respondents were also asked to determine their knowledge in different farm/crop machines and level of knowledge regarding Integrated Pest Management and Nutrient Management. Figures 10, Table 7, Figure 11 and Figure 12 describe the Participation of Women in agricultural production technologies/practices in terms of their Level of Knowledge in Farm Machines, Crop Machines, Integrated Pest Management and Nutrient Management respectively.

Volume 5 Issue 6, June 2016 www.ijsr.net 
Most women are Less knowledgeable about Hand Tractor, Plow and Thresher with 131 (54\%), 117 (48\%) and 98 (41\%) respectively. They are familiar with the use of the machines but they seldom use these for the machines are heavy. However, they are not knowledgeable with Tiller, Seeder and Harvester with 120 (50\%), 131 (54\%) and 87 (36\%). In Vegetable Production, women farmers are very knowledgeable in using plow with $66(27 \%)$ women using it. Two respondents $(0.8 \%)$ form Villa Aurora, Diadi use a wooden stick to till and plant corn seeds. This used of stick of tilling and planting indicates the adaptability of women depending on the contour of the land. Since their lands are slopes with big stones, the use of carabao is not conducive in tilling the land which might cause further erosion and even landslides

Table 7: Frequency Distribution of the Participation of Women in terms of their Knowledge in Crop Machines

\begin{tabular}{|c|c|c|}
\hline Crop Machines & Frequency & Percent \\
\hline \multicolumn{3}{|l|}{ Plow } \\
\hline Not knowledgeable & 12 & 5.0 \\
\hline Less knowledgeable & 53 & 22.0 \\
\hline Very knowledgeable & 66 & 27.4 \\
\hline \multicolumn{3}{|l|}{ Others (Stick) } \\
\hline Very knowledgeable & 2 & .8 \\
\hline
\end{tabular}

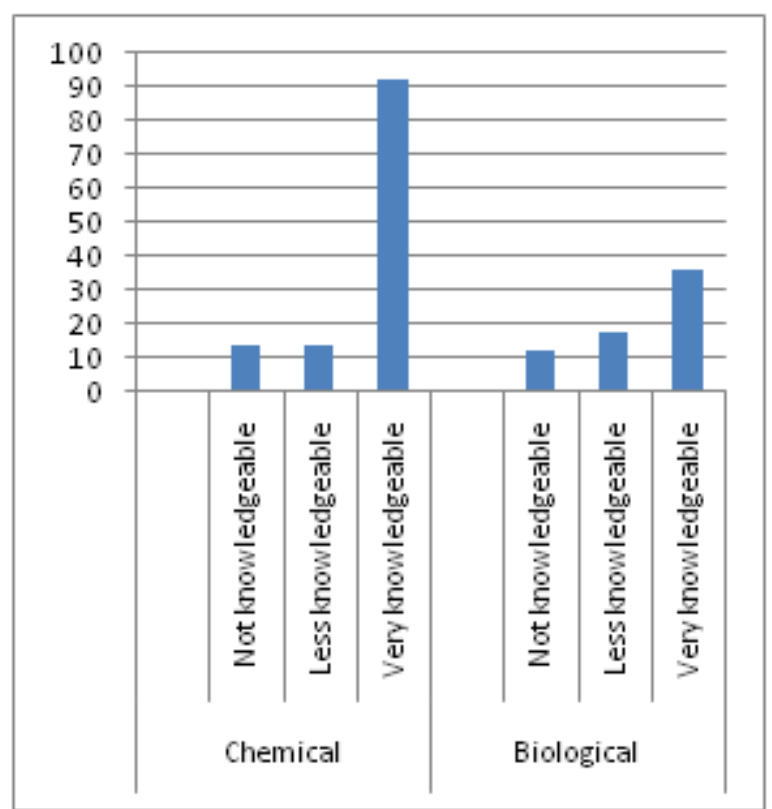

Figure 11: Frequency Distribution of the Participation of Women in terms of their Knowledge in Integrated Pest Management

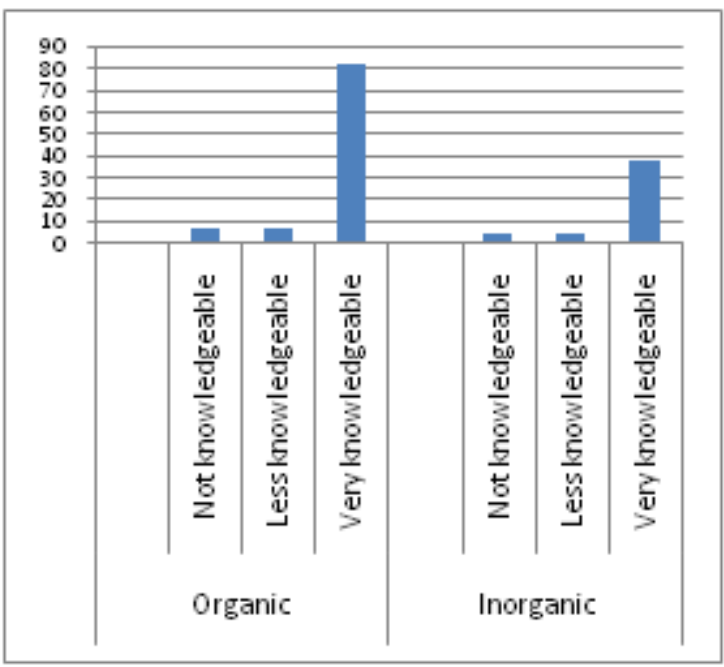

Figure 12: Frequency Distribution of the Participation of Women in terms of their Knowledge in Nutrient Management

In terms of their level of knowledge regarding Integrated Pest Management and Nutrient Management, Figures 11 and 12 indicate that women farmers are very knowledgeable regarding the different insecticide/fungicide/pesticides and fertilizer they use. The widespread knowledge is due to the zealous efforts of companies to promote their products. Seminars and training are regularly conducted to inform farmers how these products promoted by the companies are used. There were more $92(38 \%)$ of women who were very knowledgeable in utilizing chemical integrated pest management than 36 (14\%) of women who knows biological pest management. In terms of Nutrient Management, they are Very Knowledgeable in using chicken dung and other Organic fertilizers with 83 (34\%) of women respondents. They are very knowledgeable in using inorganic fertilizers with 38 (15\%) women who buy and use commercially-made fertilizers.

Table 10: Frequency Distribution of Women Indicating their Attendance/Participation in seminar/training

\begin{tabular}{|c|c|c|}
\hline Response & Frequency & Percent \\
\hline Yes & 129 & 53.5 \\
\hline No & 112 & 46.5 \\
\hline
\end{tabular}

Tables 10 and 11 show the participation of women indicating their attendance/participation in seminars/trainings and topic/s discussed in those seminars/trainings respectively. There are more women who attend seminars/ training with 129 (53.5\%) than those who do not attend with $112(46.5 \%)$. The common topics discussed were Nutrient Management with 81 (34\%), Family Planning with 47 (20\%), and Water Management with $37(15.4 \%)$.

Table 11: Frequency Distribution of Women Indicating the Topic/s focused of Seminar/Training they have attended

\begin{tabular}{|l|c|c|}
\hline Topic/s & $\begin{array}{c}\text { Frequen } \\
\text { cy }\end{array}$ & $\begin{array}{c}\text { Perce } \\
\text { nt }\end{array}$ \\
\hline Production & 32 & 13.3 \\
\hline Integrated Pest Management & 34 & 14.1 \\
\hline Nutrient Management & 81 & 33.6 \\
\hline Water Management & 37 & 15.4 \\
\hline $\begin{array}{l}\text { Others (Family } \\
\text { Planning/Reproductive Health) }\end{array}$ & 47 & 19.5 \\
\hline
\end{tabular}

D. Economic Contribution of Women in Performing Productive, Managing and Reproductive Work

Table 10: Frequency Distribution of Women Indicating Major Activities They Perform

\begin{tabular}{|l|c|c|}
\hline Activities & Frequency & Percent \\
\hline Household chores & 177 & 73.4 \\
\hline Student & 8 & 3.3 \\
\hline Hired Labor (On Farm) & 110 & 45.6 \\
\hline Hired Labor (Off Farm) & 1 & 0.4 \\
\hline
\end{tabular}

Rural Women of Nueva Vizcaya usually perform household chores. Table 10 indicates that there are 177 (73\%) respondents perform household chores. They are the plain housewives who cater to the needs of their families. A good number of the respondents are involved in hired labor (On farm) with $110(46 \%)$. In order to contribute to the income of the family, most women work in the farm aside from attending to the needs of their families. Though most women who are hired in the farm, they do not necessarily gain additional income since it was more of bayanihan system in their community.

The number of hours spent in the different agricultural activities differs for rural men and women in performing Productive Works/Agricultural Development in Crop/Vegetable Production. In terms of Preparation, more women respondents $60(25 \%)$ indicated that they spent 6-7 hours while their male counterpart spent $2-3$ hours. In Seed Purchase, 26 (10.8) women will spend 4 hours in purchasing 


\section{International Journal of Science and Research (IJSR)}

ISSN (Online): 2319-7064

Index Copernicus Value (2013): 6.14 | Impact Factor (2015): 6.391

seeds. They explained that buying the seeds will only take them few minutes but the travel time especially waiting for the schedule of jeepney/public utility vehicle passing takes much of their time. So aside from the seed purchase they also take this opportunity as a time to sell their proucts, buy necessary supplies for their homes and community. For sowing, 15 (6.2\%) of women involved spent $4-5$ hours. Their male counterparts only spent 1-2 hours. The physical prowess of males enables them to work faster. Men and women spent 4 5 hours in the field planting crops. $11(4.6 \%)$ of females confirmed this information. Fertilization activity which is usually done by males takes about 2-3 hours but for 62 (26\%) females, it will take them $7-8$ hours. Both male and female farmers spent 2 -3 hours doing Pest Management. 120 (50\%) of the females said that spraying of pesticides are done in the early morning and late afternoon.

A lesser number of respondents indicated that they perform Managing Works/Social or Community Development Activities. 9 (3.7\%) respondents informed the researchers that they are elected barangay officials, officer of their association and other Managerial tasks and that they spent $4-5$ hours. Whereas their male counterparts spent 8 and above hours for he is an elected barangay captain. Only women perform domestic and marketing/sales activities with $3(1.2 \%)$ and 4 $(1.7 \%)$ respectively. They usually spent $4-5$ hours cleaning houses and backyard, washing clothes, caring for youngsters and others.

Most reproductive works/Household Development activities are done by women. They spent $0-1$ hour performing household tasks. 203 (84\%), 151 (13\%), 198 (82\%), 201 (83.4\%), $196(81 \%), 110(46 \%)$ and $139(58 \%)$ of women perform Cooking, Feeding, washing dishes, Washing Clothes, Cleaning, Preparing children to go to school and siesta respectively.

Table 11.shows the daily productive, managing, reproductive activities of women and their corresponding economic value of 150 per day. The average wage per day in the 7 areas is Php 150 with merienda and Php 200 without food.

Take note however, that these managing and reproductive activities of women are not compensatory with money- these activities do not have salary. They are free. But should these be given monetary value, this could imply additional economic contribution of women in the family.

E. Capacitating the women farmers through Practical Knowledge and Viable Technologies: The Result of FocusGroup Discussion
As stated in the methodology part, the FGD was used to substantiate and complement the quantitative data gathered. This part is a qualitative data were themes are generated from the voices of women farmers in different field sites. So, a training-seminar was designed for women farmers.

The title of the seminar-training was “ TiningngKababaihangMagsasaka: A Gender Sensitive Livelihood Training Program held at DFTC, Nueva Vizcaya State University last March 13-14, 2014. These were participated by more than 30 women farmers from Villa Aurora, Diadi, Buliwao, Quezon and Parai, Dupax Del Norte.

The first part were different lectures given by pool of experts from different institutions like Philippine Commission on Women and University of the Philippines Los Banos. It started with the overview of watershed development and management in Nueva Vizcaya. After this lecture, the women farmers were now ready to the second talk about equipping them with basic gender concepts that enable them to realize their greater part and role in the community and society. With these knowledge, they have come to fully appreciate their roles as farmers as the third lecture highlights the NVSU own-based technology- the Field- Based Monitoring System. This technology helps the women farmers to appreciate the different climatic conditions and agricultural patterns. Afterwhich, the women farmers were able to process all these practical knowledge through the FGD.

Through the FGD, the women were tasked community mapping where they were able to locate the different resources in their respective community plus the PLACE of women in these resources. They were also able to identify the risks, hazards, potential empowerment of women in the household decision-making, political venues and economic contribution. This first part prepared the women farmers to the main event which are the hands-on technology that enrich and capacitate them as women farmers.

The second part were hands-on about food-processing, mushroom production and organic farming and fertilizer. These technologies were truly appreciated by the women farmers as these give them additional income in their family especially when their products are processed and are able to sell them. These are off-farm activities that women can do to contribute economically even though most of their time were allotted in reproductive activities that are not compensated. By these technologies, they come to truly realize their potentials as economic contributors and thereby realized also that by doing so, they have empowered themselves.

Table 11: Implied Economic Contribution of Women in a Day (ie January - Rice)

\begin{tabular}{|c|c|c|c|}
\hline \multirow[t]{2}{*}{ Time of the Day } & \multicolumn{3}{|c|}{ Activities } \\
\hline & Productive & Managing & Reproductive \\
\hline 4: $00-5: 00$ & & & Cooking (1) \\
\hline $5: 01-6: 00$ & Feeding (Animal Production) & & Cleaning (2) \\
\hline $6: 01-7: 00$ & $\begin{array}{c}\text { Land Preparation (Crop/ Vegetable } \\
\text { Production) }\end{array}$ & & $\begin{array}{c}\text { Feeding (1) } \\
\text { Washing - clothes (3) } \\
\text { Washing - Dishes (1) } \\
\text { Preparing Children to go to school (1) }\end{array}$ \\
\hline $7: 01-8: 00$ & $\begin{array}{c}\text { Land Preparation (Crop/ Vegetable } \\
\text { Production) }\end{array}$ & & \\
\hline $8: 01-9: 00$ & $\begin{array}{c}\text { Land Preparation (Crop/ Vegetable } \\
\text { Production) }\end{array}$ & & \\
\hline 9:01-10:00 & $\begin{array}{c}\text { Land Preparation (Crop/ Vegetable } \\
\text { Production) }\end{array}$ & & \\
\hline 10:01-11:00 & Herding (Animal Production) & & Cooking (1), Feeding (1) \\
\hline 12:01-1:00 & & & $\begin{array}{l}\text { Washing - clothes (3) } \\
\text { Washing - Dishes (1) }\end{array}$ \\
\hline 1:01-2:00 & & & Siesta (1) \\
\hline Total Amount Paid (Php) & $(300)$ & & $(450)$ \\
\hline
\end{tabular}

Volume 5 Issue 6, June 2016 www.ijsr.net 


\section{International Journal of Science and Research (IJSR)}

ISSN (Online): 2319-7064

Index Copernicus Value (2013): 6.14 | Impact Factor (2015): 6.391

F. Level of Awareness, participation, adaptation and mitigation \& sustainability practices on Watershed Development

Table 12: Frequency Distribution of Women in terms of their Awareness of Observed Climatic/Environmental Hazards \& Problems

\begin{tabular}{|c|c|c|}
\hline $\begin{array}{c}\text { Observed } \\
\text { Climatic/Environmental } \\
\text { Hazards \& Problems }\end{array}$ & Frequency & Percentage \\
\hline Typhoon and Flooding & 137 & 53.8 \\
\hline El Nino & 164 & 68 \\
\hline Air Pollution & 43 & 17.8 \\
\hline Water Pollution & 42 & 17.4 \\
\hline Solid Waste Management & 49 & 20.3 \\
\hline Degradation of Watershed & 43 & 17.8 \\
\hline
\end{tabular}

Table 13: Frequency Distribution of Women in terms of their Awareness of Perceived Causes

\begin{tabular}{|c|c|c|}
\hline Perceived Causes & Frequency & Percentage \\
\hline Anthropogenic - individual \& household & 153 & 63.5 \\
\hline Anthropogenic - change of land use & 92 & 38.2 \\
\hline Anthropogenic - Institutional activities & 54 & 22.4 \\
\hline
\end{tabular}

Table 14: Frequency Distribution of Women in terms of their Awareness of Perceived Effects

\begin{tabular}{|c|c|c|}
\hline Perceived Effects & Frequency & Percentage \\
\hline Loss of Life & 70 & 29 \\
\hline Poor Health & 125 & 51.9 \\
\hline Loss /damage to property & 93 & 38.6 \\
\hline Water shortage & 96 & 39.8 \\
\hline Lack of safe water & 96 & 39.8 \\
\hline Loss of Biodiversity & 43 & 17.8 \\
\hline Loss of land Productivity & 38 & 15.8 \\
\hline
\end{tabular}

Table 15: Frequency Distribution of Women in terms of their Awareness of Adaptive Capability

\begin{tabular}{|c|c|c|}
\hline Adaptive Capability & Frequency & Percentage \\
\hline 3r and Segregation & 77 & 32 \\
\hline Household Technical Solution & 70 & 29 \\
\hline Socio cultural Practices & 41 & 17 \\
\hline Agricultural Practices & 174 & 72.2 \\
\hline
\end{tabular}

Tables 12, 13, 14 and 15 show the Demographic Profile of Women when grouped according to their Awareness of Observed Climatic/Environmental Hazards \& Problems, Perceived Causes, Perceived Effects and Adaptive Capability respectively. Most women $164(68 \%)$ perceived that the most observed climatic/environmental hazards \& problems is drought. This is followed by typhoon and flooding with 137 (54\%). Therewere153 (64\%)womenwho believed that the perceived cause is Anthropogenic - individual \& household. The activities of people and families greatly influence drought and flooding. The kainginsystem, burning of waste especially plastic-based waste can contribute to these climatic conditions. These women perceived that climatic problems can cause poor health, shortage of water and potable drinking water and may eventually lead to loss of life. The adaptive capability that most of them can do are Agricultural Practices with 174 (72\%), 3R and Segregation with 77 (32\%), Household technical Solutions with $70(29 \%)$ and Socio cultural practices with $41(17 \%)$. The respondents believed that they can be active participants in adapting and mitigating activities for climate change.

\section{Conclusion}

The following are the findings and conclusion:

1. The Agricultural Profile of the Rural Women of Nueva Vizcaya is characterized by:

a) They have less than 1 hectare land area.

b) They own the land that they till. c) Rice, corn and vegetables like tomato, string beans and others are the common crops that they plant and harvest. They also take care of mallard duck, cattle and carabao. These animals are used in the farm.

2. The participation of Women in Agricultural Production Technologies/Practices include:

a) Rural women are more engaged in different activities in crop/vegetable production like Planting, Fertilization and Harvesting

b) In Animal/Livestock Production rural women are more engaged in feeding, herding and marketing

c) The level of knowledge in the different farming and crop machines is lesser compared to their knowledge in Integrated Pest Management and Nutrient Management. The role of advertisements and trainings of commercial companies has a great impact.

d) They have attended different seminars like Nutrient Management intended to sell different chemical fertilizers and family planning and reproductive health seminar.

3. The economic contribution of women in performing productive, managing and reproductive work include

a) Rural women of Nueva Vizcaya usually perform household chores and thus it is not compensated. Though there are $46 \%$ of women who perform hired labor on farm, they do not also receive compensable for in the community bayanihan system is practiced.

b) In performing productive work in crop/vegetable production like planting, seed purchase, fertilization and others, compensation are not given for they own the land and/or they are helping their husband. If these productive work will be compensated, they will earn Php 150 - 300 a day for different tasks in crops/vegetable production and animal/livestock production.

c) They spent most of their time at home performing reproductive work. If these reproductive chores will be compensated they will earn Php $150-450$ per day for different task like caring for youngsters, washing clothes, cleaning of house and others.

d) During the focused group discussion, women asserted their greater role in the community especially with the managing of different resources that could empower them economically. They have pointed out that there are risks and hazards faced by these women farmers but somehow these are not given with utmost attention

4. The level of awareness, participation, adaptation and mitigation \& sustainability practices

a) El Nino/drought - climatic/environmental hazards and problems.

b) Anthropogenic - individual and household cause these climatic problems. These activities include cutting down and burning of trees, kaingin system

c) They are willing to actively participate and cooperate with officials and concerned agencies if there are projects to lessen the effect of high temperature like planting trees and segregation of waste.

d) In the focused group discussion, the off-farm activities like food processing their own products (ginger-making, tomato sauce making), making walis-tambo, environmentalfriendly business like recycling-bakalbote), women farmers have additional economic contribution even though most of their time were allotted in reproductive activities that are not compensated. By these technologies, they come to truly realize their potentials as economic contributors and thereby realized also that by doing so, they have empowered themselves. 


\section{Recommendations}

a) Policies about women should be strengthened even at the grassroots level. Their role and part in the family, community and society are deemed necessary that could not be neglected as this study shown.

b) The government should be serious in implementing viable technologies for women empowerment- and these should be long-term and not short term only. The allocation of fund should be given priority.

c) THE FUTURE TRAJECTORY OF THIS RESEARCH: Women are necessary part of the society and how should our government be given priority especially with their HEALTH: MATERNAL HEALTH

\section{References}

[1] RA 7192.1991.an act prescribing on the Role of Women as Equal and Full Partner of Men in Nation building. Malacañang, Philippines

[2] DumlaoF.S., 2000. Economic Contribution of Women in Fishery Development.DMMSU.Bacnotan , La union

[3] Corpuz L., F. Dumlao and M. Leones, 1976. The role of Women in Agricultural Development.DMMSU, Bacnotan, La Union 